Journal of Plant and Environmental Research
(ISSN: 2475-6385)

\title{
REFLECTION OF THE ANTHROPIC IMPACT ON SPECIES AND POPULATION OF THE BARRA DE CATUAMA BEACH (GOIANA-PE)
}

\author{
Marcos Vinícius da Silva Alves de Lima1* Matheus Alves Siqueira de Assunção' Ingrid \\ Andrêssa de Moura' ${ }^{1}$ Maria Eduarda dos Santos Pereira de Oliveira ${ }^{1}$ Anna Thereza de \\ Oliveira Barbosa' Anna Claudia Santos Mendonça', Fálba Bernadete Ramos Anjos2.
}

${ }^{1}$ Graduandos do curso de Ciências Biológicas - Bacharelado, Centro de Ciências Biológicas, Universidade Federal de Pernambuco; 2 Professor Doctor of the Federal University of Pernambuco (UFPE)

\section{ABSTRACT}

Objective: The objective of this article is to make an analysis of the anthropic impact on the lo-cal species of Barra de Catuama beach, which is located in the Southeast of the municipality of Goiana, Pernambuco. Methods: For this purpose, we used the methodology of analysis of pho-tos, reading articles published about the subject, and the tools found on the internet, such as news and videos. Results: Through analysis of photos and bibliography, it was possible the perception of the anthropic impact relactive to social, environmental and economic's quality, in Barra de Catuama beach, since the presence of solid waste and domestic sewage accounted in the decrease of species of the region and of tourists. Conclusion: The conclusion of this ana-lyzes is that the ecological and public damage, prevent the recreation of the bathers and have a direct influence on the fishing and catching crabs, those are one of the main sources of income in the region, stressing that this anthropic impact resulted in the decrease of the population of the species, and a deviation of the local income.

Keywords: Barra de Catuama; impact; analyze; anthropic.

*Correspondence to Author: Marcos Vinícius da Silva Alves de Lima; Graduandos do curso de Ciências Biológicas - BachaHow to cite this article:

Marcos Vinícius da Silva Alves de Lima Matheus Alves Siqueira de Assunção Ingrid Andrêssa de Moura1 Maria Eduarda dos Santos Pereira de Oliveira Anna Thereza de Oliveira Barbosa Anna Claudia Santos Mendonça, Fálba Bernadete Ramos Anjos. REFLECTION OF THE ANTHROPIC IMPACT ON SPECIES AND POPULATION OF THE BARRA DE CATUAMA $B E A C H$ (GOIANA-PE). Toxicological effects of Ambrosia maritima in Nubian goats. Journal of Plant and Environmental Research, 2019,3:11 relado, Centro de Ciências Biológicas, Universidade Federal de Pernambuco. 


\section{INTRODUCTION}

The municipality of Goiana is inserted in the Northern Forest of the state of Pernambuco with a vegetation a characteristic that reflects in the culture and the fixation of the man in the middle.

The embossed predominantly Goiana part of the unit boards and a small coastal area of the municipality is inserted in the drive Coastal Baixadas, characterized in salt marshes, swamps and dune s (CPRM / PRODEEM, 2005) 1 . In general it has deep soils and low natural fertility. The climate is Rainy Tropical type with dry summer. This one municipality is inserted, geologically, the Borborema Province, being made up of the rock types (Rocha defined based on certain selected physical characteristics) of Salgadinho and Strands complex, the Beberibe Formation of the Barreiras Group and Deposits Fluvio -marinhos, Fluvio -lagunares and Aluvionares (CONSUPLAN, 2012) ${ }^{2}$. The main bodies of accumulation are the reservoirs: Jacaré, Bombeiro, da Mata, Santa Tereza, da Prata and Lagoa de Catuama. All water courses in the municipality have a perennial flow regime and the drainage pattern is dendritic. (CPRM Geological Survey of Brazil) Project for the registration of sources of water supply in the sub terranean. Diagnosis of the municipality of Goiana, state of Recife ( CPRM / PRODEEM, $2005)^{1}$.

The Catuama beach is one of the busiest beaches on the northern coast of Pernambuco in the summer. The temperature of the river is very high, with its average temperature of $24^{\circ} \mathrm{C}$ per year. The beach has some of the richest areas of the northeastern coast in biodiversity. There is also a lagoon called "do Gomes" what resists illegal landfills by overflowing its waters into small streams into the sea during the rainy season (Code of Civil Procedure for the Aggravation of an Instrument AGTR 56569 PE 20004.05.017725-4 (TRF-5) ${ }^{3}$.

Barra de Catuama receives continental influence through several fluvial water bodies, highlighting the Catuama rivers, Butterbur, Botafogo and Congo (MACÊDO, 1974) ${ }^{4}$. In contrast to the southern segment of the SEI, the northern segment is characterized by a diverse topography, with a wide and varied bathymetry, where there are extremely flat and shallow stretches, and morphologically rugged sites, with several sandbanks and mud that appear in the low -mar and valleys submerged in a "V" (Lira, 1975;. MACÊDO et al, 2000) ${ }^{5}$.

Coastal areas, and particularly the estuaries with their impressive mangroves, are characterized by high productivity and harbor very complex ecosystems, being considered by Day Jr. et al. (1989). In addition, they are associated with brackish water and are composed of typical woody plant species, as well as micro and macroalgae, and present favorable conditions for feeding, protection and reproduction of many species of animals (SCHAEFFER-NOVELLI, 1995; REBELO \& MEDEIROS, 1988).

The goal of ste study was to analyze the factors involved are in the anthropic impact on resident species of Catuama beach bar which is in the southeastern city of Goiana, Pernambuco.

\section{MATERIALS AND METHOD}

The research was conducted on the beach of Barra de Catuama ( $07^{\circ} 35^{\prime} 44,2$ "S 034ㄴ 53' 30" W ), with semi-annual monitoring. Data were collected and photographic records on coastal erosion and mangrove and its species, bibliographic queries in an attempt to clarify the reflections of $r$ atio $n$ Anthropogenic on the health of the population in 2017 to 2018 interscticios.

To complement the information, we analyzed videos found on the search sites, on interviews with residents about the action of the authorities and the pollution of the beach.

\section{RESULTS AND DISCUSSION}

It was observed that there was an interference in the studied environment, since there was an increase of the constructions in the surroundings of the mangrove and the coastal region.

People's behavior influenced the landscape due to continued the production of garbage and improper disposal, that is, the slopes of the 
village houses, whose garbage was deposited directly in the Coastal Ecosystem (Figure 1) .

Among the remains were identified plastic bags, pieces of wood, plastic buckets, bottles PET's, cans, household appliances, construction debris: pieces of bricks and tiles, wood and shards of glass, possibly fruit of the actions of the residents. We also identified some containment attempts in this area (Figure 1).
The impact is extended until I Mangrove Ecosystem. Domestic litter was evidenced in the mangrove, buildings, sewage draining into the mangrove, domesticated animals feeding in this environment (figure 2).

The mangrove is also threatened, with domestic sewage from houses being thrown directly into this habitat. Was evidenced the presence of directed shackles for this environment (figure 3 ).

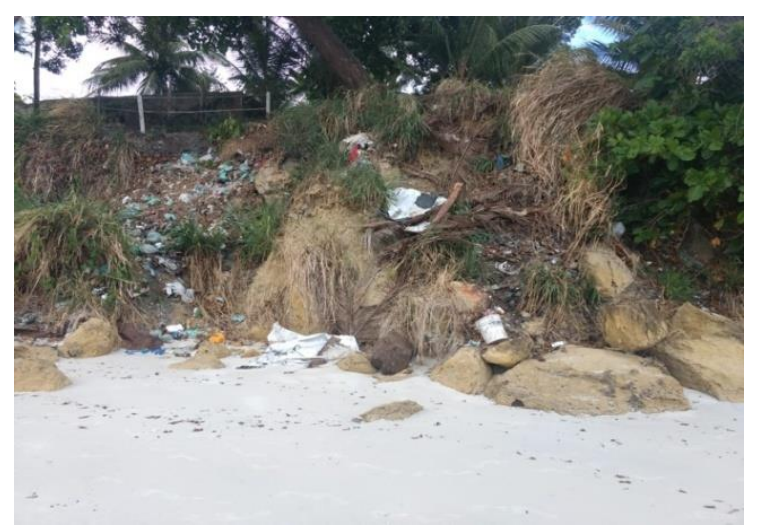

Figure 1. Solid waste deposited on the slopes of houses.

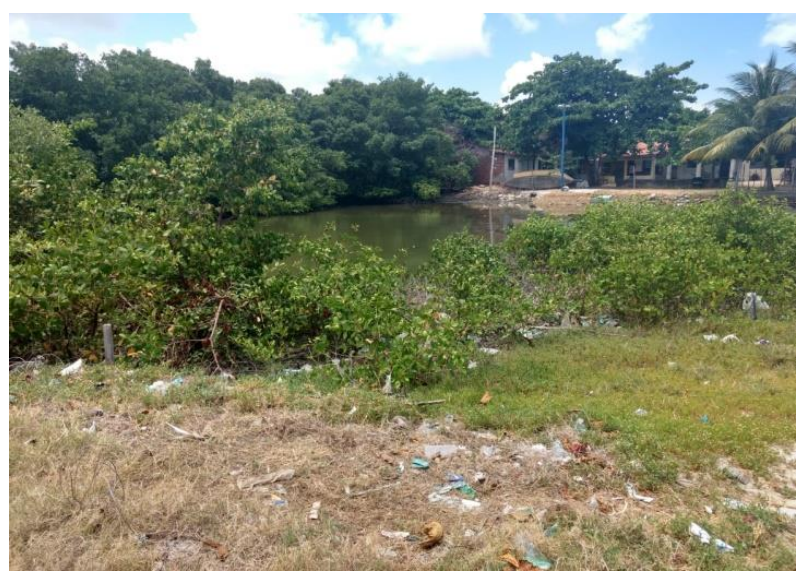

Figure 2. Mangrove and masonry constructions of local residents and pollution.

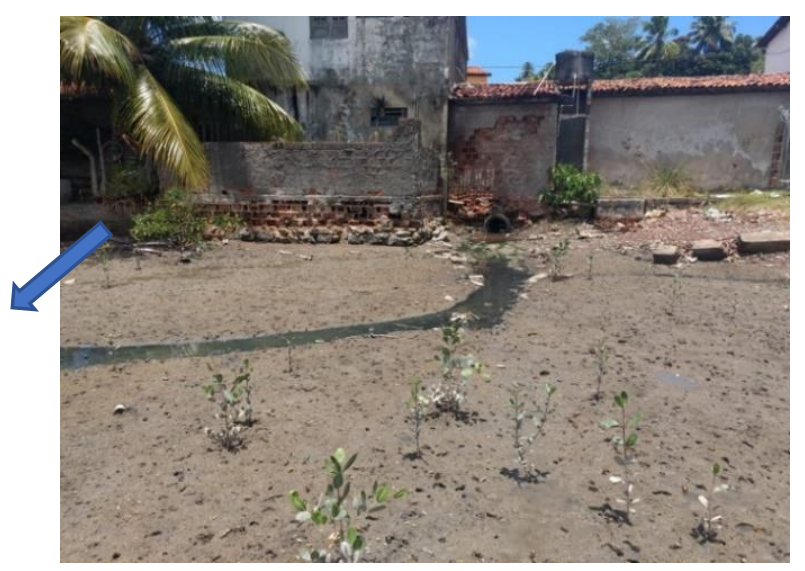

Figure 3. Domestic sewage and irregular mangrove constructions. 
The concept of Ecosystem involves the functional relationships between organisms and their physical environment. In this context we highlight the food chains from which the energy of the Ecosystems flows and the path along which the essential chemical elements to life move through them. (EHRLICH, EHRLICH, $1974)^{6}$.

The causes and socioeconomic context have repercussions on public health and animal development, since mangroves are considered the nurseries of several groups of different animals, reflecting their high biological productivity (DIEGUES, 2002) ${ }^{7}$.

One fact that called attention was that even being a mangrove area, the environment has been modified. The Mangrove has a whole legal system of environmental preservation, which translates as a permanent zone of protection, but there is a shortage of manpower in the Secretariats and in the Ministry of the Environment (Oliveira, 2017) ${ }^{8}$.
In Brazil, unfortunately, there is the dumping of waste in rivers and seas. Mangrove Ecosystems suffer directly from pollutant load influences, such as in urban areas. The behavior of the Brazilian population considered the mangrove as a dirty and stinking place, ready to receive garbage

(http://www.mma.gov.br/estruturas/sqa_pnla/_a rquivos/manguezais.pdf) ${ }^{9}$.

The residents of this studied area survive from fishing, extract the bivalves that are trapped the roots of the mangrove vegetation, capture decapods and other cultures that surround, as endorsed in the literatures (Oliveira, 2017). The problem goes beyond an environmental issue, but surrounding the areas of public health, education and especially the social part of the residents who survive the raw material collected there.

It was identified that garbage is not limited to "backyards" (Figure 3), they invaded the roots of the plants associated with mangroves (Figure 4).

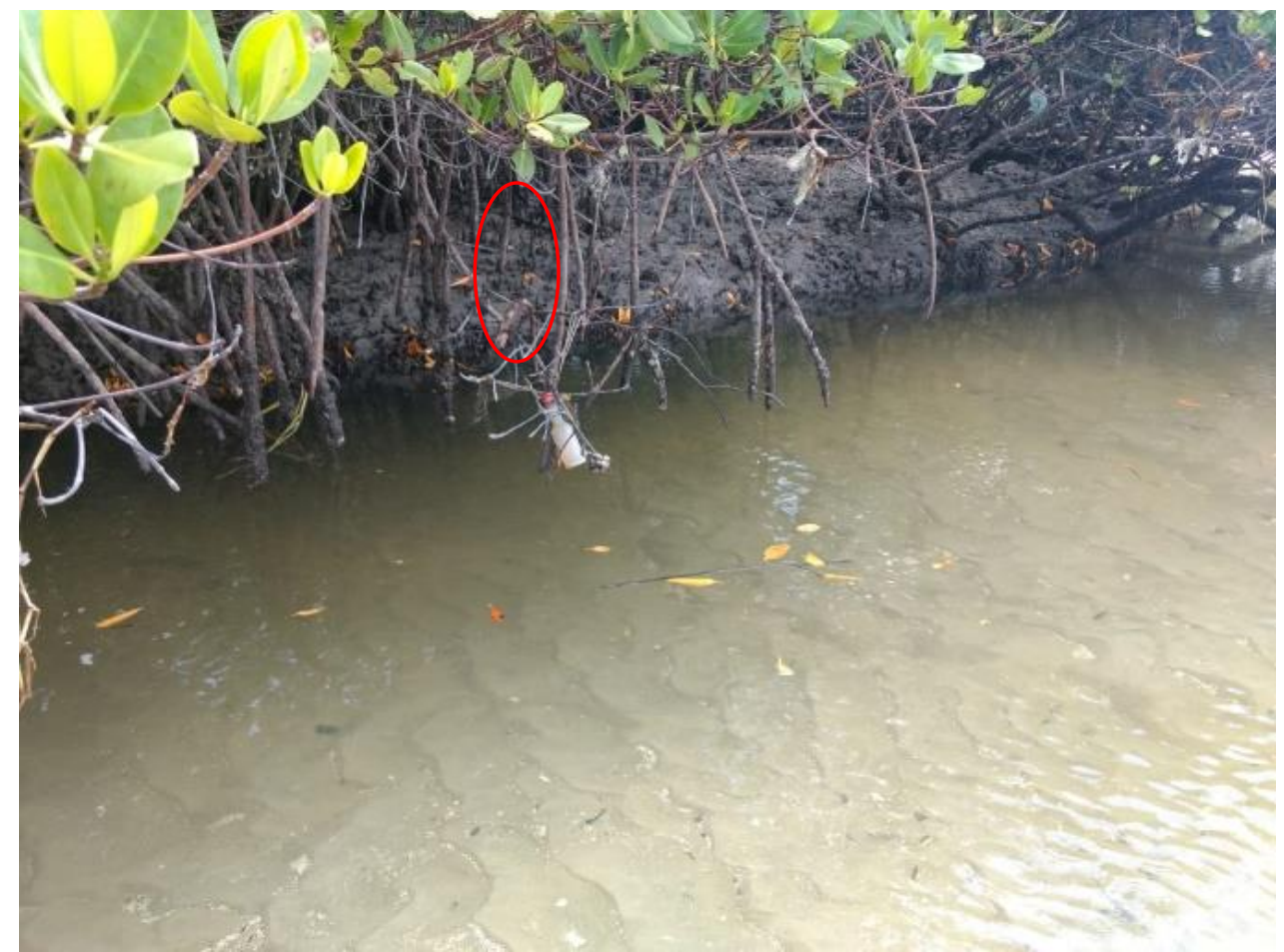

Figure 4. Plastic bottle (red circle) between the roots of the Mangue.

Another point that attracted attention was the absence of bathers and consequently the tourism potential not explored, water pollution, imbalance on the population. 
According to (BARBOZA, 2008) ${ }^{10}$, in the last years the environmental impacts have caused the population decrease of these species, causing that the residents have to look for other profitable activities.

Species are being extinguished over time, perhaps because of economic exploitation such as habitat destruction, mainly because $50 \%$ or more of the world's animal species live in the tropics. Genetic heritage in the face of a destructive situation is lost, when habitats suffer from the deterioration and loss of reserves (BASTOS, FREITAS, 2004) ${ }^{11}$.

Association between man and the coastal environment has contributed to the progressive degradation of waters affecting marine waters due to domestic sewage and industrial sewage polluting, contaminating the waters by biological and chemical agents that cause disease (NOGUEIRA, 1993) $^{12}$. These data cited above corroborate our assessments.

\section{CONCLUSION}

Considering the aspects observed in Barra de Catuama Beach, it was evidenced that the main anthropic effects consisted in the deposition of solid residues, possibly it can influence the quality of life and the biodiversity of the ecosystems of this region.

The Mangrove ecosystem has several important functions for the environmental balance, functioning as a biological indicator for the modifications of the coastline, due to the rapid response of its plant species to any change in the environment. It is the ecosystem that responds most strongly to geomorphological and sedimentary processes. In highly urbanized coastal areas, the erosion process is seen as a serious problem in view of the losses caused by this phenomenon (NOGUEIRA, D.P. 1993) ${ }^{12}$.

The mangrove is one of the most important ecosystems in the entire ecosystem of the SEI, as it is responsible for a series of ecological products and functions that directly influence the productivity of the entire system (Schuler et al, 2000) ${ }^{13}$.

\section{REFERENCES}

1 CPRM-Serviço Geológico do Brasil Projeto cadastro de fontes de abastecimento por água subterrânea. Diagnóstico do município de Goiana, estado de Recife

2 Código de Processo Civil Agravo Regimental no Agravo de Instrumento AGTR 56569 PE 20004.05.017725-4 (TRF-5

3 MACÊDO, S. J. Fisioecologia de alguns estuários do Canal de Santa Cruz (Itamaracá/PE). Dissertação (Mestrado em Fisiologia Geral), Universidade de São Paulo. São Paulo. 1974, $121 \mathrm{f}$.

4 LIRA, L. Geologia do Canal de Santa Cruz e praia submarina adjacente à llha de Itamaracá - PE. Dissertação (Mestrado em Geociências), Universidade Federal do Rio Grande do Sul, Porto Alegre, 1975. $107 \mathrm{p}$.

5 MACÊDO, S. J.; FLORES-MONTES, M. de J.; LINS, Y. C. Características abióticas da área. In: BARROS, H. M.; ESKINAZI-LEÇA, E.; MACEDO, S. J.; LIMA, T. Gerenciamento Participativo de Estuários e Manguezais. Recife: Ed. Universitária da UFPE, 2000. cap. 2, p. 7-25. 2000

6 EHRLICH, Paul R, População, recursos, ambiente: problemas de Ecologia humana por Paul EHRLICH e Anne H. EHRLICH; tradução de José Tundisi. São Paulo, Polígono, Ed. Da Universidade de São Paulo, 1974) 6 .

7 DIEGUES, A. C. Povos e Águas - Inventário de áreas úmidas brasileiras. 2 ed. São Paulo. Nupaub/USP, 2002. p 15-18.).

8 Oliveira, J. A. R. ZONEAMENTO AMBIENTAL E OCUPAÇÃO TERRITORIAL GEOGRÁFICO DO DISTRITO DE PONTAS DE PEDRA NO MUNICÍPIO DE GOIANA LITORAL NORTE DE PERNAMBUCO - BRASIL.

9

http://www.mma.gov.br/estruturas/sqa_pnla/_arquiv os/manguezais.pdf

10 BARBOZA, 2008, FUI NO MANGUE CATAR LIXO, PEGAR CARANGUEJO, CONVERSAR COM O URUBU": ESTUDO SOCIOECONÔMICO DOS CATADORES DE CARANGUEJO NO LITORAL NORTE DE PERNAMBUCO. Rev. Bras. Enga. Pesca 3(2), jul. 2008

11 BASTOS, Freitas, 2004) AGENTES E PROCESSOS DE INTERFERÊNCIA, DEGRADAÇÃO E DANO AMBIENTAL Cap. 1, página 17.

12 NOGUEIRA, D.P. 1993. Gestão e monitoramento do meio ambiente litoral: aspectos da saúde pública. Anais do III Simpósio de Ecossistemas da Costa Brasileira. São Paulo: ACIESP, 2: 233- 237 
Marcos Vinícius da Silva Alves de Lima et al., JPER, 2019, 3:11

13 SCHULER, C. A. B; ANDRADE, V. C. \& SANTOS,

Estuários e Manguezais. Recife: Ed. Universitária da D. S. O manguezal: composição e estrutura. In:

UFPE, 2000. cap. 3, p. 27-38. 2000.

BARROS, H. M.; ESKINAZI-LEÇA, E.; MACEDO, S.

J.; LIMA, T. Gerenciamento Participativo de

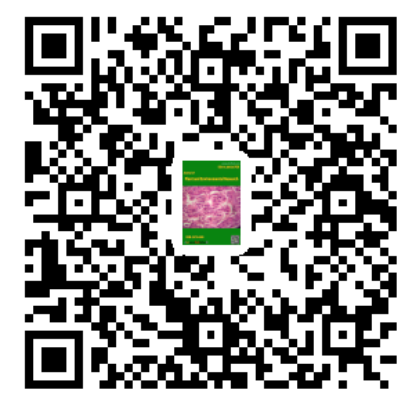


Marcos Vinícius da Silva Alves de Lima et al., JPER, 2019, 3:11 